\title{
Erratum to: can dynamic light improve melatonin production and quality of sleep?

HI Jensen ${ }^{1,2^{*}}$, TD Thomsen ${ }^{1}$, JW Larsen ${ }^{1}$ and J Markvart ${ }^{3}$

Unfortunately, the original version of this article [1] contained an error. The author's names and affiliations have not been included correctly. The correct names and affiliations are:

HI Jensen ${ }^{1,2^{*}}$, TD Thomsen ${ }^{1}$, JW Larsen ${ }^{1}$ and J Markvart ${ }^{3}$

* Corresponding author: Hanne Irene Jensen, Hanne.Irene.Jensen@rsyd.dk

${ }^{1}$ Kolding Hospital, part of Lillebaelt Hospital, Kolding, Denmark

${ }^{2}$ Institute of Regional Health Research, University of Southern Denmark

${ }^{3}$ Danish Building Research Institute/Aalborg University, Copenhagen, Denmark

\section{Author details}

${ }^{1}$ Kolding Hospital, part of Lillebaelt Hospital, Kolding, Denmark. ${ }^{2}$ Institute of Regional Health Research, University of Southern Denmark, Odense,

Denmark. ${ }^{3}$ Danish Building Research Institute/Aalborg University,

Copenhagen, Denmark.

Received: 31 July 2015 Accepted: 3 August 2015

Published online: 04 September 2015

\section{Reference}

1. Jennings, Thomsen, Larsen, Markvardt. Can dynamic light improve melatonin production and quality of sleep? Critical Care. 2014:18:14.

* Correspondence: Hanne.Irene.Jensen@rsyd.dk

The online version of the original article can be found under doi:10.1186/ cc13204

'Kolding Hospital, part of Lillebaelt Hospital, Kolding, Denmark

${ }^{2}$ Institute of Regional Health Research, University of Southern Denmark,

Odense, Denmark

Full list of author information is available at the end of the article

\section{Submit your next manuscript to BioMed Central} and take full advantage of:

- Convenient online submission

- Thorough peer review

- No space constraints or color figure charges

- Immediate publication on acceptance

- Inclusion in PubMed, CAS, Scopus and Google Scholar

- Research which is freely available for redistribution 